JURNAL BASICEDU

Research \& Learning in Elementary Education

https://jbasic.org/index.php/basicedu

\title{
Pengaruh Penggunaan Model Discovery Learning Dan Motivasi Terhadap Kemampuan Berpikir Kritis Peserta Didik Sekolah Dasar
}

\author{
Syiti Mutia Hasnan ${ }^{1}$, Rusdinal ${ }^{2}$, Yanti Fitria ${ }^{3}$ \\ Universitas Negeri Padang, Sumatera Barat, Indonesia ${ }^{1,2,3}$ \\ Email: $\underline{\text { hasnansyitimutia@gmail.com }}{ }^{1}$, rusdinal@fip.unp.ac.id ${ }^{2}$, yanti fitria@ fip.unp.ac.id ${ }^{3}$
}

\begin{abstract}
Abstrak
Jenis penelitian ini adalah penelitian eksperimen semu (quasi eksperimen). Desain yang digunakan dalam penelitian ini adalah desain faktorial (2x2), dengan Pengetahuan awal sebagai variabel moderator. Hasil penelitian menunjukan: 1 . Hipotesis 1 , diperoleh $F_{\text {hitung }}$ sebesar 34,4 dan $F_{\text {tabel }} 3,95$, karena $F_{\text {hitung }}$ lebih besar dari $\mathrm{F}_{\text {tabel }}(34,4>3,95)$ maka $\mathrm{H}_{0}$ ditolak dan $\mathrm{H}_{\mathrm{I}}$ diterima. Dengan begitu dapat diartikan bahwa kemampuan berpikir kritis peserta didik yang di ajar dengan model Discovery Learning lebih baik daripada kemampuan berpikir kritis peserta didik yang diajar dengan pembelajaran konvensional, 2. hipotesis II juga diperoleh $F_{\text {hitung }}$ sebesar 17,2 dan $F_{\text {tabel }} 3,95$, karena $F_{\text {hitung }}$ lebih besar dari $F_{\text {tabel }}(17,2>3,95)$ maka $\mathrm{H}_{0}$ ditolak, $H_{I}$ diterima. Hal ini berarti bahwa motivasi belajar yang dimiliki peserta didik yang diajarkan dengan model pembelajaran Discovery Learning lebih baik dari pada motivasi peserta didik yang diajarkan dengan model pembelajaran konvensional yang menggunakan metode diskusi, 3. Hipotesis III diperoleh $\mathrm{F}_{\text {hitung }}$ sebesar 11,4 dan $F_{\text {tabel }} 3,95$ Karena $F_{\text {hitung }}$ juga lebih besar dari $F_{\text {tabel }}(11,4>3,95)$ maka $\mathrm{H}_{0}$ ditolak dan $\mathrm{H}_{\mathrm{I}}$ diterima. Disimpulkan bahwa terdapat interaksi yang signifikan antara model Discovery Learning dengan motivasi peserta didik kemampuan berpikir kritis peserta didik.
\end{abstract}

Kata Kunci: discovery learning, motivasi belajar, berpikir kritis

\begin{abstract}
This type of research is pseudo-experimental research (quasi-experiment). The design used in this study is a factorial (2x2) design, with initial knowledge as a moderator variable. The results showed: 1. Hipotesis1, with F Test, acquired f count of 34.4 and $\mathrm{F}$ table 3.95 because Fcount $>$ Ftabel then $\mathrm{H}_{0}$ rejected and $\mathrm{H}_{\mathrm{I}}$ received. It can be interpreted that the critical thinking skills of learners with the Discovery Learning model are better than the student's critical thinking skills taught by conventional learning. 2. Hypothesis II also acquired fcount of 17.2 and Ftabel 3.95, because Fcount > of Ftabel, then H0 rejected, HI acceptable. This means that learning motivation that learners have taught with Discovery Learning learning models is better than learners motivations taught with conventional learning models that use discussion methods. 3. Hypothesis III with Ftest obtained fcount of 11.4 and Ftabel 3.95. Because Fcount $>$ than Ftabel then $\mathrm{H}_{0}$ is rejected and $\mathrm{H}_{\mathrm{I}}$ is received. It was concluded that there was a significant interaction between the Discovery Learning model and the motivation of students ' critical thinking skills.
\end{abstract}

Keywords: Discovery Learning, motivation learning, critical thinking

@ Jurnal Basicedu Prodi PGSD FIP UPTT 2020

$\triangle$ Corresponding author :

Address :-

Email :-

ISSN 2580-3735 (Media Cetak)

Phone :- 
240 Pengaruh Penggunaan Model Discovery Learning dan Motivasi terhadap kemampuan berpikir kritis peserta didik sekolah dasar - Syiti Mutia Hasnan, Rusdinal, Yanti Fitria

\section{PENDAHULUAN}

Terciptanya karakter dan pendewasaan diri seseorang itu karena adanya pendidikan yang mampu mewujudkan potensi diri, kecakapan dan keterampilan dalam diri seseorang. Dapat disadari perlunya membentuk anak - anak yang terampil memecahkan masalah, bijaksana dalam mengambil keputusan, berpikir kritis dan inovatif serta mampu bekerja keras secara individu maupun kelompok. Untuk mewujudkan karakter dan pendewasaan diri tersebut diperlukan adanya Pendidikan yang mampu meningkatkan kualitas Sumber Daya Manusia (SDM) dalam menjamin keberlangsungan pembangunan suatu bangsa. Berdasarkan Undang - Undang Sistem Pendidikan Nasional (UUSPN) No. 20 tahun 2003 Bab I Pasal 1 mengatakan bahwa Pendidikan adalah usaha sadar dan terencana untuk mewujudkan suasana belajar dan proses belajar agar peserta didik secara aktif mengembangkan potensi dirinya untuk memiliki kekuatan, spritual keagamaan, pengendalian diri, kepribadian, kecerdasan, akhlak mulia, serta keterampilan yang diperlukan dirinya dalam bermasyarakat, berbangsa dan bernegara. Pendidikan dituntut harus berorientasi pada pengembangan kemampuan peserta didik.Untuk menjadi manusia yang seperti dikemukakan dalam UUSPN di atas, maka peserta didikperlu mengolah semua informasi yang relevan secara kritis.

Sesuai dengan maksud pendidikan tersebut, salah satu yang perlu dikembangkan adalah kemampuan berpikir kritis peserta didik. Pentingnya kemampuan berpikir kritis melalui proses pendidikan adalah untuk mengembangkan sikap, mampu memperoleh dan mengintegrasikan pengetahuan serta mampu menyelesaikan berbagai masalah atau persoalan sehingga peserta didik memiliki kemampuan untuk bersaing pada skala global sesuai perkembangan zaman. Untuk itu di Sekolah Dasar (SD) diperlukan adanya pengembangan kemampuan berpikir kritis peserta didik yang tinggi sehingga siap untuk terjun di masyaraka, khususnya dalam pembelajaran IPA dan Bahasa Indonesia. Pada pembelajaran IPA diharapkan peserta didik mempunyai kemampuan berpikir kritis untuk mempersiapkan dirinya menjadi pemecah masalah yang tangguh, pembuat keputusan yang matang, dan menjadi seorang individu yang tidak pernah berhenti untuk belajar mencari, menganalisis, menganalisa dan mengkonsepkan informasi. Sedangkan pada pembelajaran Bahasa Indonesia yang berbasis teks diharapkan juga mampu untuk berpikir kritis dalam mengidentifikasi, memahami, memecahkan masalah dan mengaplikasikan materi pembelajaran.

Adapun kenyataannya berpikir kritis tidak begitu menjadi tujuan utama dalam tujuan pembelajaran di Sekolah Dasar. Kegiatan pembelajaran di Sekolah Dasar umumnya masih menggunakan pembelajaran konvensional. Pembelajaran konvensional merupakan pembelajaran tradisional yang selalu digunakan pada kegiatan sehari- hari dalam proses belajar dengan metode ceramah sebagai alat komunikasi lisan yang diiringi dengan penjelasan, kemudian pembagian tugas dan latihan (Djamarah, 2011). Peserta didik disini adalah penerima yang pasif, dimana mereka hanya menerima pengetahuan dari guru dan diasumsinya sebagai badan informasi yang menjadikan pengetahuan bersifat final. Dengan begitu belum terlihat pembelajaran yang menitik beratkan pada kemampuan berpikir kritis, sehingga selama proses maupun hasil belajar menjadi kurang memuaskan.

Model pembelajaran Discovery Learning adalah sebuah model pembelajaran memahami konsep, arti, dan hubungan, melalui proses penalaran rasional dan intelektualitas untuk akhirnya sampai kepada suatu kesimpulan (Fitria, 2018). Discovery Learning ini lebih menekankan pada ditemukannya konsep atau prinsip yang 

peserta didik sekolah dasar - Syiti Mutia Hasnan, Rusdinal, Yanti Fitria

sebelumnya tidak diketahui. Oleh karena itu, pendidik harus memberikan kesempatan peserta didiknya untuk menjadi seorang pemecah masalah (problem solver) yang nantinya melakukan berbagai kegiatan dalam menghimpuninformasi,membandingkan,mengkate gorikan,menganalisis,mengintegrasikan, mengorganisasikan dan membuat kesimpulan. Pendidik sebagai seorang pembimbing yang berperan selama proses pembelajaran, menciptakan proses belajar secara aktif, merubah kegiatan belajar mengajar menjadi berorientasi kepada peserta didik (Student Oriented) dan mengarahkan kegiatan belajar peserta didik sesuai dengan tujuan pembelajaran.

Selain itu, ketika pendidik memberikan suatu pernyataan dengan fokus pembelajaran IPA pada materi Sistem Organ Pencernaan peserta didik kurang dapat memberikan alasan atau pendapat berkaitan dengan jawaban yang diberikan. Jawaban yang diberikan peserta didik hanya sebatas hafalan yang bersifat mengingat, tanpa memiliki suatu konsep yang mendasar. Indikasinya adalah keingintahuan peserta didik terhadap suatu konsep materi belajar itu rendah. Karena bagi mereka, apa yang dijelaskan oleh guru adalah semua yang menyangkut tentang materi yang dipelajari. Hal ini disebabkan karena sumber pengetahuan yang dimiliki peserta didik hanya berasal dari pendidik.

Melalui paparan di atas sebuah Penelitian Trend in International Mathematics and Science Study (TIMSS) tahun 2015 mendiagnosa hasil mutu pencapaian kemampuan peserta didik dalam bidang Sains/ IPA secara umum, peserta didik Indonesia lemah di semua aspek konten maupun kognitif, baik untuk Sains dan mata pelajaran lainnya. Pada penelitian tersebut juga di ketahui bahwa lemahnya peserta didik dalam berbagai aspek juga di dukung dengan hal - hal yang sudah mereka ketahui tetapi belum bias mengaplikasikannya dengan benar. Peserta didik Indonesia hanya menguasai soal- soal yang bersifat, rutin, sederhana dan bersifat keseharian, sedangkan untuk soal- soal yang bersifat kritis, menganalisis dan butuh pemahaman mereka tidak mampu untuk menjelaskannya. Penelitian tersebut memperkuat indikasi bahwa pembelajaran di Indonesia masih belum maksimal. Rendahnya kualitas pembelajaran terlihat dari kurang berkembangnya anak dalam memahami konsep ilmiah serta pembelajaran kurang terintegrasi dan fleksibel dalam kehidupannya. Oleh karena itu pembelajaran hendaknya memberikan pengalaman secara langsung kepada peserta didik agar mampu mengembangkan dan menerapkannya dalam kehidupan sehari - hari.

Adapun faktor lain yang mendukung terjadinya pembelajaran yang bermakna bagi peserta didik adalah dengan sebuah motivasi belajar. Motivasi belajar peserta didik juga sangat mempengaruhi permasalahan pada proses pembelajaran di Sekolah Dasar (SD) khususnya pada motivasi ekstrinsiknya. Motivasi ekstrinsik merupakan daya dorong, kekuatan yang berasal dari luar diri peserta didi, yang terlihat dari minat, keingintahuannya dalam belajar. Peserta didik yang memiliki motivasi tinggi selalu berusaha mengikuti proses pembelajaran dengan sebaikbaiknya untuk memperoleh kemampuan berpikir yang optimal dan berasal dari peserta didik yang memiliki peringkat terbaik di kelas. Sedangkan beberapa peserta didik lainnya memiliki motivasi yang dapat dikatakan rendah dalam proses belajar. Melihat masih rendahnya kemampuan berpikir kritis serta motivasi belajar peserta didik ini, maka perlu adanya model pembelajaran yang dapat melatih kemampuan berpikir kritis dan rasa ingin tahu mereka. Model pembelajaran yang tepat adalah model pembelajaran yang memberikan ruang kepada peserta didik untuk terlibat langsung secara aktif pada saat proses pembelajaran, yaitu 

peserta didik sekolah dasar - Syiti Mutia Hasnan, Rusdinal, Yanti Fitria

salah satunya dengan model pembelajaran discovery learning.

Model pembelajaran discovery learning merupakan suatu model pembelajaran dimana pendidik tidak banyak memberikan penjelasan namun lebih banyak kepada pengajuan pertanyaanpertanyaan sehingga peserta didik menjadi lebih aktif dan termotivasi dalam pembelajaran. Aktifnya peserta didik juga di dukung dengan adanya motivasi sebagai pendorong dalam pembelajaran. Penelitian (Dafrita, 2017) menyatakan bahwa pembelajaran dengan model discovery learning dapat mempengaruhi pemahaman dan kemampuan berpikir kritis peserta didik dengan mempertimbangkan faktor-faktor yang ikut serta berpengaruh dalam mendorong belajar peserta didik.

\section{METODE}

Jenis penelitian ini adalah penelitian eksperimen semu (quasi eksperimen). Penelitian quasi eksperiment adalah model penelitian yang digunakan untuk mencari pengaruh terhadap yang lain dalam kondisi yang terkendalikan. Untuk mencari pengaruh tersebut, peneliti dengan sengaja melakukan penelitian. Sejalan dengan hal itu Suryabrata (2009) menjelaskan quasy eskperimen ini dilakukan untuk memperoleh informasi yang diperoleh dengan eksperimen yang sebenarnya dalam keadaan mengontrol dan memanipulasikan semua variabel yang relevan

Desain yang digunakan dalam penelitian ini adalah desain faktorial (2x2), dengan Pengetahuan awal sebagai variabel moderator. Desain penelitian ini seperti digambarkan dalam tabel 2 berikut:
Tabel 1.Desain Faktorial 2 x 2

\begin{tabular}{|l|l|l|}
\hline $\begin{array}{l}\text { Model } \\
\text { Pembelajaran } \\
\text { Motivasi }\end{array}$ & $\begin{array}{l}\text { Model } \\
\text { Discovery } \\
\text { Learning } \\
\text { (Eksperimen) } \\
\text { A1 }\end{array}$ & $\begin{array}{l}\text { Metode } \\
\text { Konvensional } \\
\text { (Kontrol) A2 }\end{array}$ \\
\hline $\begin{array}{l}\text { Motivasi } \\
\text { Tinggi (B1) }\end{array}$ & A1B1 & A2B1 \\
\hline $\begin{array}{l}\text { Motivasi } \\
\text { rendah (B2) }\end{array}$ & A1B2 & A2B2 \\
\hline
\end{tabular}

Keterangan :

A1B1 Kemampuan berpikir kritis siswa bermotivasi tinggi yang memperoleh pembelajaran dengan menggunakan model pembelajaran Discovery Learning

A2B1 Kemampuan berpikir kritis siswa bermotivasi tinggi yang memperoleh pembelajaran dengan menggunakan model pembelajaran konvensional

A1B2 Kemampuan berpikir kritis siswa bermotivasi rendah yang memperoleh pembelajaran dengan menggunakan modelpembelajaran Discovery Learning

A2B2 Kemampuan berpikir kritis siswa bermotivasi rendah yang memperoleh pembelajaran dengan menggunakan model pembelajaran konvensional

Pada penelitian ini populasinya adalah seluruh peserta didik sekolah dasar kelas $\mathrm{V}$ yang berada di Gugus II Nan Sabaris tahun ajaran 2017/2018. Jumlah peserta didik kelas V yang ada di Gugus II Nan Sabaris tahun ajaran 2017/2018 adalah sebanyak 222 peserta didik yang berada dalam sepuluh Sekolah dasar (SD). Berdasarkan teknik pengambilan sampel kelas $\mathrm{V}$ yang terpilih kelas $\mathrm{V}$ SD Negeri 09 Nan Sabaris dijadikan kelas eksperimen dan kelas kontrol yaitu kelas V SD Negeri 22 Nan Sabaris.

Teknik pengumpulan datanya adalah angket/ kuesioner, pretest dan posttest. Pretest dan Postest digunakan untuk pengumpulan data pada kemampuan berpikir kritis. Sedangkan angket/kuesioner digunakan untuk megumpulkan data motivasi belajar.Jadi teknik pengumpulan data ini merupakan cara yang digunakan peneliti untuk mengumpulkan data dalam penelitian berupa tes dan angket. 
243 Pengaruh Penggunaan Model Discovery Learning dan Motivasi terhadap kemampuan berpikir kritis peserta didik sekolah dasar - Syiti Mutia Hasnan, Rusdinal, Yanti Fitria

Teknik analisis data yang dilakukan. Datadata yang telah dikumpulkan selanjutnya dianalisis dengan bantuan program Microsoft Excel. Data hasil tes kemampuan berpikir kritis dianalisis berdasarkan pengolahan data kuantitatif yang berupa hasil tes kemampuan berpikir kritis peserta didik. Untuk menentukan uji statistik yang digunakan, terlebih dahulu diuji normalitas data dan homogenitas variansi.

Menghitung besarnya perbedaan hasil tes kemampuan berpikir kritis diperoleh dari skor pretest dan posttest. Untuk mengetahui besarnya perbedaan hasil tes kemampuan berpikir kritis, peneliti menganalisis data hasil tes dengan normalitas gain. Kriteria normalisasi gain tersebut adalah sebagai berikut :

\section{Tabel 2}

Klasifikasi gain $<\mathrm{g}>$ Ternormalisasi

\begin{tabular}{|l|l|}
\hline Normalized gain & Kriteria \\
\hline $\mathrm{g}>0,70$ & Tinggi \\
\hline $0,30<\mathrm{g} \leq 0,70$ & Sedang \\
\hline $\mathrm{g} \leq 0,30$ & Rendah \\
\hline
\end{tabular}

Uji normalitas dilakukan untuk mengetahui apakah data berasal dari populasi yang berdistribusi normal, atau tidak. Uji normalitas dilakukan pada skor posttest dan $N$ gain pada kelas yang memperoleh pembelajaran dengan menggunakan model Discovery Learning. Dalam uji normalitas ini digunakan uji liliefors dengan kriteria uji sebagai berikut: 1. Jika nilai signifikansi ( $\mathrm{p}$-value)\&lt; $(\alpha=0,05)$, maka $\mathrm{H}$ o ditolak, 2. Jika nilai signifikansi (p-value) $\geq$ $(\alpha=0,05)$, maka H 1 diterima.

Uji homogenitas berguna untuk menentukan apakah kedua kelompok data mempunyai varians yang homogen atau tidak. Untuk uji homogenitas ini dilakukan langkah-langkah sebagai berikut:
Mencari varians masing-masing data kemudian dihitung harga $\mathrm{F}$

Jika harga sudah didapatkan maka dibandingkan $\mathrm{F}$ tersebut dengan harga $\mathrm{F}$ yangterdapat dalam daftar distribusi $\mathrm{F}$ dengan taraf signifikansi $5 \%$ dan $\mathrm{dk}$ pembilang $=\mathrm{n}_{1}-1 \mathrm{dan} \mathrm{dk}$ penyebut $=\mathrm{n}_{2}-1$. Bila harga $\mathrm{F}$ didapat dari perhitungan lebih kecil dari harga $\mathrm{F}$ yang ada ditabel berarti kedua kelompok data mempunyai varians yanghomogen dan sebaliknya (Sudjana, 2005). Berdasarkan penjelasan diatas, untuk uji $\mathrm{F}$ yang terdapat pada tabel yang belum diketahui harga dalam $F_{\text {tabel }}$ untuk menentukan bila harga $\mathrm{F}$ didapat dari perhitungan lebih kecil dari harga $\mathrm{F}$ yang ada ditabel berarti kedua kelompok data mempunyai varians yang homogen dan sebaliknya, untuk itu digunakan rumus dalam mencari interpolasi pada $F_{\text {tabel }}$ (Riduwan 2006:147).

\section{HASIL DAN PEMBAHASAN}

Berikut ini dideskripsikan data hasil penelitian yang dilaksanakan pada kelas $\mathrm{V}$ SDN 09 Kecamatan Nan Sabaris dan SDN 12 Kecamatan Nan Sabaris. Hasil penelitian berupa rerata hasil tes keterampilan berpikir kritis berdasarkan model pembelajaran, rerata hasil tes berpikir kritis berdasarkan motivasi belajar peserta didik pada pembelajaran tema lima dengan sub tema dua tentang Hubungan Antar Makhluk Hidup Dalam Ekosistem dan interaksi model pembelajaran, motivasi belajar terhadap keterampilan berpikir kritis.

Berdasarkan hasil analisis yang dilakukan pada hasil tes keterampilan berpikir kritis peserta didik pada kelas eksperimen dan kelas kontrol diperoleh nilai rata-rata, nilai tertinggi (X Max), nilai terendah (X Min), Simpangan baku (S), Variansi $\left(S^{2}\right)$ yang terlihat pada tabel. Tabel 23 di bawah ini: 
244 Pengaruh Penggunaan Model Discovery Learning dan Motivasi terhadap kemampuan berpikir kritis peserta didik sekolah dasar - Syiti Mutia Hasnan, Rusdinal, Yanti Fitria

Tabel 3. Rerata Hasil Tes Keterampilan Berpikir Kritis Berdasarkan Model Pembelajaran

\begin{tabular}{|l|l|l|l|l|l|l|}
\hline Kelas Perlakuan & N & Rata- Rata & X Max & X Min & S & S $^{2}$ \\
\hline Eksperimen & 2 & 67.36 & 89 & 49 & 13.11 & 172.02 \\
\hline Kontrol & 9 & 54.13 & 83 & 22 & 19.11 & 369.39 \\
\hline
\end{tabular}

Berdasarkan pemaparan Tabel 23 di atas, terlihat bahwa rata - rata hasil tes keterampilan berpikir kritis peserta didik berdasarkan model pembelajaran yang digunakan pada kedua kelas yakni kelas eksperimen dengan memiliki rata- rata total 67,36 dan kelas kontrol dengan memiliki ratarata 54.13. Hal tersebut menyatakan bahwa model pembelajaran yang digunakan dalam pembelajaran berpengaruh terhadap kompetensi hasil belajar peserta didik khususnya pada keterampilan berpikir kritis peserta didik pada pembelajaran sub tema 2 Hubungan Antar Makhluk Hidup Dalam Ekosistem.

Berdasarkan hasil analisis yang dilakukan pada angket motivasi belajar peserta didik pada kelas eksperimen dan kelas control diperoleh nilai rata-rata, nilai tertinggi (X Max), nilai terendah (X Min), Simpangan baku (S) dan variansi $\left(S^{2}\right)$ yang terlihat pada tabel 24 di bawah ini:

Tabel 4. Rerata Hasil Angket Motivasi Belajar Peserta didik

\begin{tabular}{|c|l|c|c|c|c|c|}
\hline $\begin{array}{c}\text { Kelas } \\
\text { Perlakuan }\end{array}$ & $\begin{array}{c}\text { Rata } \\
- \\
\text { Rata }\end{array}$ & $\begin{array}{c}\text { Ma } \\
\text { X }\end{array}$ & $\begin{array}{c}\text { X } \\
\text { Min }\end{array}$ & S & $\mathbf{S}^{2}$ \\
\hline Eksperimen & $\mathbf{3}$ & $\begin{array}{c}\mathbf{1 7 . 8} \\
\mathbf{2}\end{array}$ & $\mathbf{2 0}$ & $\mathbf{1 1}$ & $\begin{array}{c}\mathbf{3 . 0} \\
\mathbf{9}\end{array}$ & $\begin{array}{c}\mathbf{9} \\
\mathbf{6 0}\end{array}$ \\
\hline Kontrol & $\mathbf{1}$ & $\begin{array}{c}\mathbf{1 5 . 1} \\
\mathbf{0}\end{array}$ & $\mathbf{1 9}$ & $\mathbf{8}$ & $\begin{array}{c}\mathbf{2 8} \\
\mathbf{8}\end{array}$ & $\begin{array}{c}\mathbf{5} \\
\mathbf{3 6}\end{array}$ \\
\hline \multicolumn{5}{|c}{ Sumber: Data Primer, 2018 } \\
\end{tabular}

Berdasarkan table 15 di atas, terlihat bahwa rata-rata hasil angket motivasi belajar peserta didik yang diperoleh dari kedua kelas yaitu kelas eksperimen dengan rata-rata 17.82 dan kelas kontrol dengan rata-rata 15.10. Pengukuran yang telah dilakukan tersebut menyatakan bahwa motivasi belajar yang dimiliki peserta didik berpengaruh terhadap kemampuan belajar peserta didik khususnya pada keterampilan berpikir kritis peserta didik dalam pembelajaran sub tema 2 Hubungan Antar Makhluk Hidup Dalam Ekosistem.

Menguji hipotesis bertujuan untuk melihat hasil dari perlakuan yang diberikan pada sampel dalam penelitian. Hipotesis ini dilakukan setelah mengetahui hasil tes kemampuan berpikir kritis. Hipotesis 1, 2, 3 menggunakan Uji F.

Tabel 26. Hasil Uji Hipotesis Denga Uji F

\begin{tabular}{|c|c|c|c|c|c|c|}
\hline $\begin{array}{c}\text { Sum } \\
\text { ber } \\
\text { Varia } \\
\text { ns }\end{array}$ & JK & db & KR & $\begin{array}{c}\mathbf{F}_{\text {hitu }} \\
\mathbf{n g}\end{array}$ & $\mathbf{F}_{\text {tabel }}$ & $\begin{array}{c}\text { Keteran } \\
\text { gan }\end{array}$ \\
\hline $\begin{array}{l}\text { Antar } \\
\text { Grou } \\
\mathrm{p}(\mathrm{A})\end{array}$ & $\begin{array}{l}1279 \\
97.2\end{array}$ & 1 & $\begin{array}{l}127997 \\
.2\end{array}$ & 34.4 & \multirow{5}{*}{3.95} & $\begin{array}{l}\mathrm{H}_{\mathrm{I}} \\
\text { diterima }\end{array}$ \\
\hline $\begin{array}{l}\text { Antar } \\
\text { Grou } \\
\mathrm{p}(\mathrm{B})\end{array}$ & $\begin{array}{l}6420 \\
6.01\end{array}$ & 1 & $\begin{array}{l}64206 . \\
01\end{array}$ & 17.2 & & $\begin{array}{l}\mathrm{H}_{\mathrm{I}} \\
\text { diterima }\end{array}$ \\
\hline $\begin{array}{l}\text { Antar } \\
\text { Grou } \\
\mathrm{p} \\
\text { (AB) }\end{array}$ & $\begin{array}{l}4260 \\
7.89 \\
6\end{array}$ & 1 & $\begin{array}{l}42607 . \\
896\end{array}$ & 11.4 & & $\begin{array}{l}\mathrm{H}_{\mathrm{I}} \\
\text { diterima }\end{array}$ \\
\hline $\begin{array}{l}\text { Dala } \\
\mathrm{m} \\
\text { Grou } \\
\mathrm{p}(\mathrm{D})\end{array}$ & $\begin{array}{l}3118 \\
16.1 \\
16\end{array}$ & 84 & $\begin{array}{l}3712.0 \\
9\end{array}$ & - & & \\
\hline Total & $\begin{array}{l}5466 \\
27.2 \\
\end{array}$ & 87 & - & & & \\
\hline
\end{tabular}

Hasil perhitungan di atas menggunakan Uji F. Pada Hipotesis I, diperoleh $F_{\text {hitung }}$ sebesar 34.4 dan $F_{\text {tabel }} 3.95$, karena $F_{\text {hitung }}$ lebih besar dari $F_{\text {tabel }}$ maka $\mathrm{H}_{0}$ ditolak dan $\mathrm{H}_{\mathrm{I}}$ diterima. Dengan begitu dapat diartikan bahwa kemampuan berpikir kritis peserta didik yang di ajar dengan model Discovery Learning lebih baik daripada kemampuan berpikir kritis peserta didik yang diajar dengan pembelajaran konvensional. Hipotesis $\boldsymbol{I}$, pada pengujian hipotesis II juga diperoleh $\mathrm{F}_{\text {hitung }}$ sebesar 17.2 dan $F_{\text {tabel }} 3.95$, karena $F_{\text {hitung }}$ lebih besar dari $\mathrm{F}_{\text {tabel }}$, maka $\mathrm{H}_{0}$ ditolak, $\mathrm{H}_{\mathrm{I}}$ diterima. Hal ini berarti bahwa motivasi belajar yang dimiliki peserta didik yang diajarkan dengan model pembelajaran Discovery Learning lebih baik dari pada motivasi 
245 Pengaruh Penggunaan Model Discovery Learning dan Motivasi terhadap kemampuan berpikir kritis peserta didik sekolah dasar - Syiti Mutia Hasnan, Rusdinal, Yanti Fitria

peserta didik yang diajarkan dengan model pembelajaran konvensional yang menggunakan metode diskusi. Hipotesis III, diperoleh $\mathrm{F}_{\text {hitung }}$ sebesar 11.4 dan $F_{\text {tabel }}$ 3.95. Karena $F_{\text {hitung }}$ lebih besar daripada $\mathrm{F}_{\text {tabel }}$ maka $\mathrm{H} 0$ ditolak dan $\mathrm{HI}$ diterima. Disimpulkan bahwa terdapat interaksi yang signifikan antara model Discovery Learning dengan motivasi peserta didik kemampuan berpikir kritis peserta didik.

\section{HASIL DAN PEMBAHASAN}

Berdasarkan hasil analisis data kemampuan berpikir kritis peserta didik kelas V SDN 09 Nan Sabaris yang diteliti menunjukkan bahwa peserta didik yang diajar dengan model pembelajaran Discovery Learning baik secara keseluruhan, baik kelompok peserta didik yang memiliki motivasi belajar yang tinggi maupun kelompok peserta didik yang memiliki motivasi belajar rendah. Dimana terlihat dari hasil uji hipotesis yang telah dilakukan sehingga dilakukan pembahasan. Tiga pokok pembahasan yang dilakukan berdasarkan landasan teori yang relevan, yaitu: (a) model pembelajaran yang digunakan berpengaruh terhadap keterampilan berpikir kritis, (b) motivasi belajar yang dimiliki peserta didik berpengaruh terhadap keterampilan berpikir kritis, dan (c) interaksi antara model pembelajaran dan motivasi belajar mempengaruhi kemampuan berpikir kritis.

Pertama, model pembelajaran yang digunakan berpengaruh terhadap keterampilan berpikir kritis peserta didik. Dengan rerata hasil tes kemampuan berpikir kritis pada peserta didik yang diberikan perlakuan dengan model Discovery Learning adalah 67.36 atau lebih tinggi dari rerata hasil tes kemampuan berpikir kritis pada peserta didik yang di ajar dengan pembelajaran konvensional di kelas kontrol dengan rerata sebesar 54.13. Dengan begitu disimpulkan bahwa model Discovery Learning lebih baik dibandingkan dengan pembelajaran konvensional karena dalam penerapan model Discovery Learning, peserta didik lebih aktif dalam pembelajaran dari pada pembelajaran secara konvensional dengan peserta didik..

Data yang telah dianalisis juga diperkuat dengan hasil pengujian hipotesis pertama dengan menggunakan uji $\mathrm{t}$ diperoleh $\mathrm{t}_{\text {hitung }} 34.4$ dan $\mathrm{t}_{\text {tabel }}$ yang diperoleh adalah 3.95. Hal ini menunjukkan $\mathrm{t}_{\text {hitung }}$ lebih besar dari $\mathrm{t}_{\text {tabel }}$, maka $\mathrm{H}_{0}$ ditolak dan $\mathrm{H}_{\mathrm{I}}$ diterima. Dengan begitu dapat diartikan bahwa kemampuan berpikir kritis pada peserta didik yang diajar dengan model Discovery Learning lebih baik daripada kemampuan berpikir kritis pada peserta didik yang diajar dengan pembelajaran diskusi yang diajarkan dikelas kontrol.

Penelitian ini menunjukkan bahwa model Discovery Learning memberikan pengaruh yang positif terhadap kemampuan berpikir kritis. Ennis (2011:1) berpikir kritis adalah “ critical thinking is reasonable, reflective thinking that is focused on deciding what to believe or do". Defenisi ini menitik beratkan pada bagaimana cara berpikir serta memutuskan dengan masuk akal dan reflektif. Penerapan model Discovery Learning dalam pembelajaran, secara nyata peserta didik terlihat bersemangat dan aktif saat proses pembelajaran dimana peserta didik dituntut untuk menyelidiki, menemukan sendiri jawaban atas permasalahan yang diberikan oleh pendidik, dengan demikian membuat peserta didik untuk menuangkan ide dan pendapatnya masing- masing.

Penerapan model Discovery Learning berhasil mempengaruhi kemampuan berpikir kritis peserta didik. Kenyataannya hasil tes peserta didik yang mendapat perlakuan dengan menggunakan model Discovery Learning menunjukkan peningkatan dibandingkan dengan peserta didik yang tidak mendapatkan perlakuan. Pernyataan tersebut di dukung oleh Hosnan (2014: 287-288) bahwa model pembelajaran Discovery Learning memberikan kesempatan kepada peserta didik 

peserta didik sekolah dasar - Syiti Mutia Hasnan, Rusdinal, Yanti Fitria

untuk memecahkan masalah yang ditemuinya sendiri untuk melatih peserta didik belajar mandiri sehingga pengetahuan hasil belajar mudah ingat dan bertahan lama. Dengan demikian, terlihat keunggulan model tersebut sehingga bermanfaat dalam proses pembelajaran. Hal tersebut juga diperkuat dengan pendapat (Bichar et al., 2019) pembelajaran dengan menggunakan model pembelajaran Discovery Learning memberikan kesempatan kepada peserta didik untuk aktif membangun sendiri pengetahuannya, karena model pembelajaran ini tidak hanya menjadikan peserta didik belajar lebih baik tetapi juga retensi materi yang telah diperoleh akan bertahan lebih lama, dan meningkatkan kinerja peserta didik. Temuan yang didapat peserta didik akan menunjukkan efek keterlibatan peserta didik yang lebih baik,dalam menemukan konsep kritis materi yang telah dipelajari.

Penerapan Discovery Learning mendorong pendidik untuk mengetahui kapan dan bagaimana menerapkan perlakuan selama pengajaran di kelas. Jadi perbedaan pembelajaran model Discovery Learning dengan pembelajaran diskusi adalah Discovery Learning membelajarkan peserta didik untuk membangun pengetahuannya sendiri, membelajarkan peserta didik dalam memahami konsep, membelajarkan peserta didik untuk aktif dan berpikir kritis, membelajarkan peserta didik untuk berpikir kritis dengan masalah yang ditemukan, serta menjadikan pembelajaran lebih bermakna karena pengetahuan yang didapatkan peserta didik akan bertahan lebih lama (Fitria et al., 2018). Model pembelajaran Discovery Learning lebih memfokuskan pada berpikir kritis peserta didik. Peserta didik tidak lagi diberikan materi belajar secara utuh seperti bahan ajar yang ada pada pembelajaran konvensional dan dengan menggunakan model Discovery Learning maka peserta didik dapat membangun pengetahuannya sendiri.
Berdasarkan uraian di atas dari hasil penelitian dan analisis yang telah dilakukan disimpulkan bahwa model Discovery Learning memberikan pengaruh terhadap keterampilan berpikir kritis. Hal ini dibuktikan dari perbedaan nilai rata-rata hasil tes kemampuan berpikir kritis peserta didik kelas eksperimen yang diberi perlakuan dengan model Discovery Learning lebih bsik disbanding dengan kelas kontrol yang diberi perlakuan dengan kegiatan diskusi. Hasil penelitian menggunakan model Discovery Learning ini juga memperkuat hasil penelitian terdahulu yang pernah dilakukan oleh peneliti sebelumnya tentang penggunakan model Discovery Learning, seperti penelitian yang dilakukan oleh (Prasasti et al., 2019) mengemukakan bahwa keterampilan berpikir kreatif peserta didik setelah diberikan pembelajaran menemukan (Discovery Learning) mengalami peningkatan dibandingkan dengan keterampilan berpikir kreatif peserta didik yang diberikan pembelajaran secara konvensional. Selain itu, penelitian (Wedekaningsih et al., 2019) mengemukakan bahwa pembelajaran dengan model pembelajaran discovery Learning dapat meningkatkan hasil belajar peserta didik Kelas IV SDN Sukaraja Kabupaten Sumedang.

Hal ini karena dalam penerapan model pembelajaran Discovery Learning peserta didik dituntut untuk berpikir kritis, aktif dan menjadi pembelajar yang mandiri. Dimana peserta didik diajukan pada masalah untuk merangsang keingintahuan peserta didik. Peserta didik melakukan penyelidikan untuk menjawab keingintahuannya tersebut. Selanjutnya dengan melakukan penyelidikan, peserta didik menjadi pembelajar yang mandiri, dengan sendiri menemukan konsep dari materi yang dipelajari. Informasi yang didapat dari pengalaman sendiri akan lebih dipahami dan bertahan lama dalam ingatan, sehingga berimplikasi terhadap cara 
247 Pengaruh Penggunaan Model Discovery Learning dan Motivasi terhadap kemampuan berpikir kritis peserta didik sekolah dasar - Syiti Mutia Hasnan, Rusdinal, Yanti Fitria

berpikir yang terlihat dari hasil belajar yang diperoleh. Oleh karena itulah penerapan model Discovery Learning berpengaruh positif terhadap pembelajaran.

Kedua, motivasi belajar yang dimiliki peserta didik berpengaruh terhadap keterampilan berpikir kritis. Berdasarkan hasil yang diperoleh, rerata hasil tes kemampuan berpikir kritis pada peserta didik yang diajar dengan model Discovery Learning yang memiliki motivasi belajar 17.82 lebih tinggi dibandingkan dengan peserta didik yang di ajar dengan pembelajaran konvensional dengan motivasi belajar 15.10. Hal tersebut diperkuat dengan hasi pengujian hipotesis kedua yang menggunkan Uji $\mathrm{F}$ diperoleh $\mathrm{F}_{\text {hitung }}$ sebesar 17.2 dan $F_{\text {tabel }} 3.95$, karena $F_{\text {hitung }}$ lebih besar dari $\mathrm{F}_{\text {tabel}}$, maka $\mathrm{H}_{0}$ ditolak, $\mathrm{H}_{\mathrm{I}}$ diterima. Hal ini berarti bahwa motivasi belajar yang dimiliki peserta didik yang diajarkan dengan model pembelajaran Discovery Learning lebih baik dari pada motivasi peserta didik yang diajarkan dengan model pembelajaran konvensional yang menggunakan metode diskusi.

Selama proses belajar yang berlangsung di kelas eksperimen terlihat sikap peserta didik yang merespon terhadap materi yang disampaikan, karena pembelajaran yang di mulai dengan sesuatu yang menarik akan menjadikan hal yang menyenangkan bagi peserta didik. Oleh karena itu motivasi belajar juga mempengaruhi kemampuan berpikir peserta didik yang terlihat pada tingkat keberhasilan selama proses belajar. Belajar tanpa motivasi kiranya akan sulit untuk berhasil. Sebab, seseorang yang tidak mempunyai motivasi belajar, tidak akan mungkin melakukan aktivitas belajar (Hamalik, 2011:161). Peserta didik yang memiliki motivasi belajar yang baik, maka akan terlihat bersemangat dalam pembelajaran, karena peserta didik yang memiliki motivasi yang tinggi dalam belajar memiliki pengetahuan yang lebih tinggi terhadap materi yang diajarkan. Sehingga akan lebih mudah dalam mengikuti tahapan pembelajaran menggunakan Discovery Learning. Peserta didik termotivasi dalam merumuskan, menemukan dan menjawab masalah yang ditemui dalam materi pelajaran selama pembelajaran berlangsung.

Berdasarkan hasil penghitungan ketiga bahwa terdapat interaksi antara model pembelajaran dengan motivasi. Hal tersebut berdasarkan rata-rata yang telah diperoleh. Oleh karena itu apabila model pembelajaran Discovery Learning yang diajarkan dengan menggunakan motivasi maka akan menjadikan pembelajaran menjadi lebih baik, khususnya pada keterampilan berpikir kritis peserta didik rerata yang diperoleh akan cenderung lebih tinggi dibandingkan dengan model pembelajaran konvensional. Model pembelajaran dan motivasi memiliki pengaruh tersendiri terhadap proses pembelajaran. Motivasi belajar merupakan suatu pendorok peserta didik untuk aktif dalam kegiatan pembelajaran, sedangkan model pembelajaran adalah suatu pola, rancangan yang digunakan dalam mempersiapkan materi yang akan disampaikan demi tercapainya tujuan pembelajaran. Dengan begitu, adanya motivasi pada pembelajaran akan menjadikan langkah model pembelajaran menjadi tercapai sesuai tujuan belajar. Berdasarkan pernyataan tersebut disimpulkan adanya interaksi antara model Discovery Learning dan motivasi belajar terhadap kemampuan berpikir kritis peserta didik.

\section{UCAPAN TERIMA KASIH}

Artikel ini tidak akan selesai tanpa adanya bimbingan dari berbagai pihak. Untuk itu penulis mengucapkan terimakasih kepada Bapak Prof. Dr. Rusdinal, M.Pd dan Ibu Dr. Yanti Fitria, S.Pd.,M.Pd yang telah membimbing dari awal sampai akhir hingga terselesaikannya artikel ini.Serta teman-teman yang telah memberikan ide 
248 Pengaruh Penggunaan Model Discovery Learning dan Motivasi terhadap kemampuan berpikir kritis peserta didik sekolah dasar - Syiti Mutia Hasnan, Rusdinal, Yanti Fitria

dan pendapat sehingga artikel ini bias di tulis dengan baik.

\section{SIMPULAN}

Berdasarkan hasil analisis data dan pembahasan, maka dari penelitian ini dapat disimpulkan bahwa:

1. Telah dilakukan pengujian hipotesis dengan uji $\mathrm{F}$ diperoleh $\mathrm{F}_{\text {hitung }}$ sebesar 34.4 dan $\mathrm{F}_{\text {tabel }}$ 3.95, karena $\mathrm{F}_{\text {hitung }}$ lebih besar dari $\mathrm{F}_{\text {tabel }}$ maka $\mathrm{H}_{0}$ ditolak dan $\mathrm{H}_{\mathrm{I}}$ diterima. Dengan begitu dapat diartikan bahwa kemampuan berpikir kritis peserta didik yang di ajar dengan model Discovery Learning lebih baik daripada kemampuan berpikir kritis peserta didik yang diajar dengan pembelajaran konvensional.

2. Kemudian pada pengujian hipotesis II juga diperoleh $F_{\text {hitung }}$ sebesar 17.2 dan $F_{\text {tabel }}$ 3.95, karena $\mathrm{F}_{\text {hitung }}$ lebih besar dari $\mathrm{F}_{\text {tabel }}$, maka $\mathrm{H}_{0}$ ditolak, $\mathrm{H}_{\mathrm{I}}$ diterima. Hal ini berarti bahwa motivasi belajar yang dimiliki peserta didik yang diajarkan dengan model pembelajaran Discovery Learning lebih baik dari pada motivasi peserta didik yang diajarkan dengan model pembelajaran konvensional yang menggunakan metode diskusi.

3. Dan yang terakhir dilakukan pengujian dengan uji $\mathrm{F}$ diperoleh $\mathrm{F}_{\text {hitung }}$ sebesar 11.4 dan $\mathrm{F}_{\text {tabel }}$ 3.95. Karena $F_{\text {hitung }}$ lebih besar daripada $F_{\text {tabel }}$ maka H0 ditolak dan HI diterima. Disimpulkan bahwa terdapat interaksi yang signifikan antara model Discovery Learning dengan motivasi peserta didik kemampuan berpikir kritis peserta didik.

\section{DAFTAR PUSTAKA}

Bichar, A. K., Widodo, N., \& Wiyanti, H. (2019). Peningkatan Hasil Belajar Materi Perpindahan Energi Panas Menggunakan Model Discovery Learning Pada Kelas V B Sdn Ngaglik 01 Kota Batu. Jurnal Basicedu. https://doi.org/10.31004/basicedu.v3i1.106

Dafrita, I. . (2017). Pengaruh Discovery Learning

Terhadap Kemampuan Berpikir Kritis dan

$\begin{array}{lcc}\text { Analitis dalam } & \text { Menemukan } & \text { Konsep } \\ \text { Keanekaragaman } & \text { Tumbuhan. } & \text { Jurnal } \\ \text { Pendidikan Informatika Dan Sains. }\end{array}$

Ennis. 2011. Model Pembelajaran Jilid 2. Erlangga: Jakarta

Hamalik, Oemar. 2014. Motivasi dan Pengukurannya. Jakarta: Bumi Aksara

Hake, R. R. 1999. Analizyng Scorel Gain Scores. 24245 Hatteras Street Woodland Hills, CA USA

Hosnan. 2014. Pendekatan Sainstifik dan Kontekstual dalam Pembelajaran Abad 21. Bogor: Ghalia Indonesia

Fitria, Y. (2018). Perubahan Belajar Sains Siswa

Sekolah Dasar Pada Pembelajaran Terintegrasi (Terpadu) Melalui Model

Discovery Learning. Jurnal Inovasi

Pendidikan Dan Pembelajaran Sekolah Dasar.

https://doi.org/10.24036/jippsd.v2i2.102705

Fitria, Y., Hasanah, F. N., \& Gistituati, N. (2018).

Critical Thinking Skills of Prospective Elementary School Teachers in Integrated Science-Mathematics Lectures. Journal of Education and Learning (EduLearn). https://doi.org/10.11591/edulearn.v12i4.9633

Prasasti, D. E., Koeswanti, H. D., \& Giarti, S. (2019). Peningkatan Keterampilan Berpikir Kritis Dan Hasil Belajar Matematika Melalui Model Discovery Learning Di Kelas Iv Sd. Jurnal Basicedu.

https://doi.org/10.31004/basicedu.v3i1.113

Sugiyono. 2013. Metode penelitian pendidikan pendekatan kuantitatif, kualitatif, dan $R \& D$.

Suprihatiningrum. J. 2012. Strategi Pembelajaran (Teori dan Aplikasi). Yogyakarta: Ar-Ruzz Media Syah, Muhibbin. 2004. Psikologi Belajar. Bandung: PT. Remaja Rosdakarya

Siregar, Syofian. 2013. Metode Penelitian Kuantitatif Dilengkapi dengan Perbandingan Perhitungan Manual dan 
249 Pengaruh Penggunaan Model Discovery Learning dan Motivasi terhadap kemampuan berpikir kritis peserta didik sekolah dasar - Syiti Mutia Hasnan, Rusdinal, Yanti Fitria

SPSS. Jakarta: Kencana Pedana Media Group

Sisdiknas. 2012. Undang-Undang Republik

Indonesia Nomor 20 tahun 2003. Bandung:

Citra Umbara

Sugiyono. 2010. Metode penelitian pendidikan

pendekatan kuantitatif, kualitatif, dan

$R \& D$. Bandung:Alfabeta.

Sukardi. 2014. Metodologi Penelitian Pendidikan:

Kompetensi dan Praktiknya. Jakarta: Bumi Aksara

Wedekaningsih, A., Koeswati, H. D., \& Giarti, S.

(2019). Penerapan Model Discovery

Learning Untuk Meningkatkan Keterampilan

Berpikir Kritis Dan Hasil Belajar

Matematika. Jurnal Basicedu.

https://doi.org/10.31004/basicedu.v3i1.62 